\title{
The Cytokeratin Filament-Aggregating Protein Filaggrin Is the Target of the So- called "Antikeratin Antibodies," Autoantibodies Specific for Rheumatoid Arthritis
}

Michel Simon, Elisabeth Girbal, Mireille Sebbag, Véronique Gomès-Daudrix, Christian Vincent, Gilles Salama, and Guy Serre
Department of Biology and Pathology of the Cell, Toulouse-Purpan School of Medicine, University of Toulouse III, Toulouse, France

\begin{abstract}
In rheumatoid arthritis (RA), the high diagnostic value of serum antibodies to the stratum corneum of rat esophagus epithelium has been widely reported. These so-called "antikeratin antibodies," detected by indirect immunofluorescence, were found to be autoantibodies since they also labeled human epidermis. Despite their name, the actual target of these autoantibodies was not known. In this study, a 40-kD protein (designated as $40 \mathrm{~K}$ ), extracted from human epidermis and specifically immunodetected by $75 \%$ of RA sera, was purified and identified as a neutral/acidic isoform of basic filaggrin, a cytokeratin filament-aggregating protein, by peptide mapping studies and by the following evidences: ( $a$ ) mAbs specific for filaggrin reacted with the $40 \mathrm{~K}$ protein; $(b)$ the autoantibodies, affinity-purified from RA sera on the $40 \mathrm{~K}$ protein, immunodetected purified filaggrin; (c) the reactivity of RA sera to the $40 \mathrm{~K}$ protein was abolished after immunoadsorption with purified filaggrin; $(d)$ the $40 \mathrm{~K}$ protein and filaggrin had similar amino acid compositions. Furthermore, autoantibodies against the $40 \mathrm{~K}$ protein and the so-called "antikeratin antibodies" were shown, by immunoadsorption experiments, to be largely the same. The identification of filaggrin as a RA-specific autoantigen could contribute to the understanding of the pathogenesis of this disease and, ultimately, to the development of methods for preventing the autoimmune response. (J. Clin. Invest. 1993. 92:1387-1393.) Key words: autoimmunity • autoantigen • diagnosis • intermediate filament-associated protein • epidermis
\end{abstract}

\section{Introduction}

RA is the most frequent ( $1-2 \%$ of the population worldwide) human systemic autoimmune disease. It is characterized by a mononuclear cell infiltration of the synovium and by proliferation of the synovial cells. This forms an invasive pannus and leads to the destruction of articular cartilage. Although the pathogenesis of RA remains unknown, both cellular and humoral autoimmune mechanisms have been implicated (1). The presence of a wide variety of circulating autoantibodies has been described, including rheumatoid factors and antibodies to nuclear or structural cellular components (1-3). In addition,

Portions of this paper have appeared in abstract form (1992. Exp. Dermatol. 2:103).

Address correspondence to Dr. Guy Serre, Laboratoire de Biologie Cellulaire, C.H.U. Purpan, Place du Dr. Baylac, 31059 Toulouse Cedex, France.

Received for publication 1 February 1993 and in revised form 15 April 1993.

J. Clin. Invest.

(C) The American Society for Clinical Investigation, Inc. 0021-9738/93/09/1387/07 \$2.00

Volume 92, September 1993, 1387-1393 antibodies against EBV proteins have been frequently observed $(4,5)$.

In 1979, Young et al. (6) showed, using indirect immunofluorescence, the presence, in rheumatoid sera, of $\mathrm{IgG}$ antibodies labeling the stratum corneum of rat esophagus epithelium. These antibodies are clearly autoantibodies since they also react with the stratum corneum of human epidermis (6-9). They have been found to be highly specific for the disease (615 ) and their detection is now widely used as a diagnostic test for RA. Although their role has not yet been defined, they are associated with more active and/or severe forms of RA (1316) and they are detected at early stages (16) and even before the onset of joint symptoms (17), suggesting their involvement in the pathophysiology of the disease.

On the basis of their immunofluorescence pattern, these autoantibodies were thought to be directed to cytokeratins and were therefore called "antikeratin antibodies," despite the absence of any immunochemical characterization of their targets. However, preadsorption of RA sera on purified human cytokeratins did not remove their reactivity to the stratum corneum of rat esophagus (7) and we recently showed by ELISA (15) and by Western blot (Simon, M., C. Vincent, E. Girbal, M. Sebbag, V. Gomès-Daudrix, M. Haftek, and G. Serre, manuscript submitted for publication) that these autoantibodies do not recognize cytokeratins either from human epidermis or from rat esophagus. Here we report the biochemical and immunochemical characterization of the human epidermal protein detected by these RA-specific autoantibodies and its identification as filaggrin, a well known cytokeratin filament-aggregating protein (18-21).

\section{Methods}

Patients and sera. Sera were obtained from 104 patients, including 48 with classical or definite RA according to the criteria of the American Rheumatism Association (22), 37 with various inflammatory rheumatic diseases ( 10 psoriatic arthritis, 9 systemic lupus erythematosus, 10 miscellaneous connective tissue diseases, 8 ankylosing spondylitis) and 19 with noninflammatory rheumatic diseases ( 9 Paget's disease, 10 arthrosis or compressive neuralgia). Control sera were from 39 healthy adults.

Protein extraction and purification. Normal human breast epidermis was cleaved from dermis by heat treatment and homogenized in $0.2 \mathrm{ml} / \mathrm{cm}^{2}$ of an ice-cold solution containing $40 \mathrm{mM}$ Tris- $\mathrm{HCl}, \mathrm{pH}$ 7.4, $150 \mathrm{mM} \mathrm{NaCl}, 5 \mathrm{mM}$ EDTA, $0.5 \%$ Nonidet $\mathrm{P}-40,0.1 \%$ sodium azide, and $0.1 \mathrm{mM}$ phenylmethylsulfonyl fluoride. The lysate was centrifuged at $15,000 \mathrm{~g}$ for $10 \mathrm{~min}$ to get a clear detergent extract of human epidermis. Proteins of this extract were precipitated with absolute ethanol, recovered by centrifugation at $15,000 \mathrm{~g}$ for $10 \mathrm{~min}$, and resuspended in water after 20 min drying at $80^{\circ} \mathrm{C}$. The cloudy suspension thus obtained was centrifuged to obtain a clear supernatant, the partially purified $40-\mathrm{kD}$ protein, designated as the $40 \mathrm{~K}$ protein throughout our discussion.

To further purify the $40 \mathrm{~K}$ protein, this partially purified fraction was submitted to SDS-PAGE and electrotransferred to immobilonPVDF membranes (Millipore Corp., Bedford, MA). The 40K protein 
was eluted from the membranes with Triton X-100, as previously described (23). The detergent was then removed by chromatography on Extracti-Gel ${ }^{\mathrm{TM}} \mathrm{D}$ (Pierce Chemical Co., Rockford, IL) as described by the manufacturer and the purified $40 \mathrm{~K}$ protein finally desalted by gel filtration on a PD-10 column (Pharmacia LKB, Uppsala, Sweden). Human filaggrin was purified from epidermis as previously reported (23). Protein concentration was measured using the Bio-Rad Protein Assay (Bio-Rad Laboratories, Munich, Germany).

Gel electrophoresis and Western blot. Proteins were analyzed by SDS-PAGE on $12.5 \%$ acrylamide gel or by two-dimensional electrophoresis using the PhastSystem ${ }^{\mathrm{TM}}$ as described by Pharmacia LKB, the manufacturer. Protein markers from Bio-Rad Laboratories (Richmond, CA) were used as molecular weight references and the pI gradient profiles shown were indicated by the Broad pI Calibration Kit of Pharmacia LKB run in parallel.

After electrophoresis, proteins were electrotransferred to reinforced nitrocellulose membranes (Schleicher \& Schuell, Dassel, Germany) and probed, as reported (23), with various sera diluted to $1 / 50$ and visualized by peroxidase-conjugated goat antibodies to human IgG, or with $\mathrm{mAb}$ ascites diluted to $1 / 200$ and visualized with peroxidase-conjugated sheep antibodies to mouse IgG. $\mathrm{AKH} 1$, an $\mathrm{IgG}_{1} \mathrm{mAb}$ directed against human filaggrin, was purchased from Biomedical Technologies, Inc. (Stoughton, MA). Six other $\mathrm{mAbs}\left(\mathrm{IgG}_{1}\right)$ to human epidermal filaggrin purified as described above were recently produced and characterized in our laboratory (Simon, M., C. Vincent, E. Girbal, M. Sebbag, V. Gomès-Daudrix, and G. Serre, manuscript in preparation).

Determination of the amino acid composition. The amino acid composition of the purified $40 \mathrm{~K}$ protein was determined in duplicate, after acid hydrolysis, using conventional methods (Neosystem, Strasbourg, Frarice).

Immunoprecipitation. Before immunoprecipitation, the detergent extract of human epidermis was precleared with Protein-A Sepharose (Sigma Chemical Co., St. Louis, $\mathrm{MO}$ ) and made $1 \mathrm{M}$ for $\mathrm{NaCl}$; the test or control mAb was added and, after a $2-\mathrm{h}$ incubation at $37^{\circ} \mathrm{C}$, immune complexes were collected for $1 \mathrm{~h}$ with protein-A Sepharose and centrifuged for $2 \mathrm{~min}$. The precipitates were washed twice with $10 \mathrm{mM}$ Tris- $\mathrm{HCl}, \mathrm{pH} 8$, containing $0.5 \mathrm{M} \mathrm{NaCl}$ and $0.1 \%$ Nonidet $\mathrm{P}-40$, and boiled in SDS-PAGE sample buffer.

Affinity purification of the anti-40K autoantibodies. The anti-40K autoantibodies were immunoaffinity-purified from RA sera on nitrocellulose-bound $40 \mathrm{~K}$ antigen as previously reported (24) with the following modifications: the bound antibodies were eluted with $10 \mathrm{mM}$ 3-[cyclohexylamino]-1-propanesulphonic acid- $\mathrm{NaOH}, \mathrm{pH} \mathrm{12,} \mathrm{con-}$ taining $0.2 \%$ gelatin, neutralized by the addition of 0.01 vol of $2 \mathrm{M}$ Tris- $\mathrm{HCl}, \mathrm{pH} 6.8$, and immediately used.

Indirect immunofluorescence. Indirect immunofluorescence analysis was done on rat esophagus cryosections, as previously described (14).

Immunoadsorption experiments. RA sera $(2 \mu \mathrm{l})$ or the affinity-purified antibodies were preincubated for $2 \mathrm{~h}$ at $4^{\circ} \mathrm{C}$ in the presence of $6 \mu \mathrm{g}$ of protein dissolved in water, before being used in Western blot or indirect immunofluorescence.

Peptide mapping. One-dimensional peptide maps of purified filaggrin and purified $40 \mathrm{~K}$ antigen were obtained by the method described by Cleveland et al. (25) using $20 \%$ acrylamide gels. The digestions were carried out in the gel for 20 min with Staphylococcus aureus V8 protease (Sigma Chemical Co.). The protein concentrations of filaggrin and the $40 \mathrm{~K}$ antigen were approximately equal ( $3 \mu \mathrm{g}$ per lane). After electrophoresis, digested proteins were transferred and analyzed by Western blot as described above.

\section{Results}

Specificity of $R A$ sera for a $40 K$ protein. While searching, by Western blot, for RA antibody-reactive molecules, we noted the presence in human epidermis extracts of a diffuse band

A

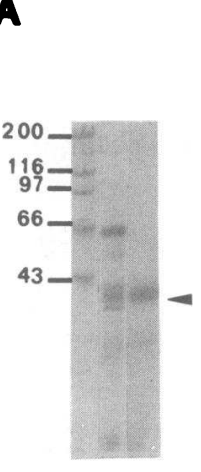

S 12
B



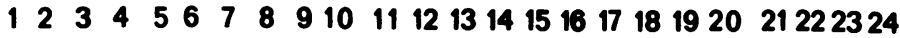

C

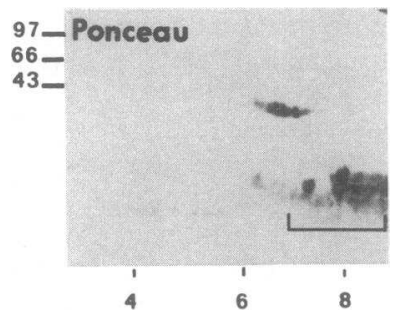

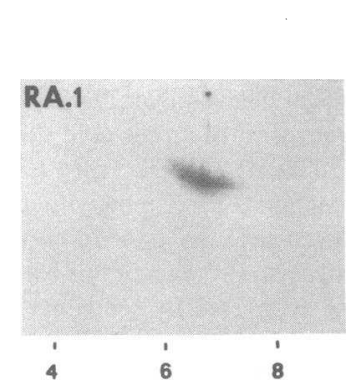

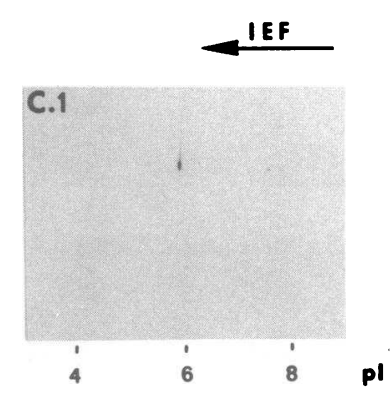

Figure 1. Characterization of a human epidermal antigen defined by RA sera. $(A)$ A detergent extract of human epidermis was precipitated by ethanol; the insoluble proteins were resuspended either in SDS-PAGE sample buffer (lane 1 ) or in water (lane 2). After clarification by centrifugation, both fractions ( 11 and $2 \mu \mathrm{g}$ of proteins, respectively) were analyzed by Coomassie blue-stained SDS-gel. A $40 \mathrm{~K}$ protein $(\triangleright)$ was selectively dissolved in water, thus being considerably purified. $S$ indicates molecular weight standards $\left(\times 10^{-3}\right)$. $(B)$ This partially purified $40 \mathrm{~K}$ protein ( $1.5 \mu \mathrm{g}$ per lane) was analyzed by Western blot with the fols lowing sera: RA, sera from patients with RA; C, control sera from healthy individuals; ORD, sera from patients with other rheumatic diseases; numbers indicate patient code. The $40 \mathrm{~K}$ protein was detected by most RA sera (lanes $1-6,8,9)$ but only by few others (lane 24$)$. (C) The partially purified $40 \mathrm{~K}$ protein $(10 \mu \mathrm{g})$ was ana-

lyzed by Western blot after two-dimensional gel electrophoresis. The nitrocellulose membranes were stained with Ponceau (note the ampholytes $[\sqcup]$ in the lower part of the membrane) and probed with a RA serum (RA.1) or with a control human serum (C.1). The 40K antigen presented a number of isoforms with pIs ranging from 5.8 to 7.4 . 
with an apparent molecular weight of $37-40,000$ decorated by most RA sera. The molecule was confirmed to be a protein by digestion with proteinase $\mathrm{K}$. It showed an unusual solubility property: when a detergent-containing lysate was precipitated with absolute ethanol, it selectively dissolved upon resuspension in water, whereas the other proteins were irreversibly precipitated (Fig. 1 $A$ ). Taking advantage of this property of the $40 \mathrm{~K}$ protein in order to partially purify it, we tested its reactivity, after SDS-PAGE, by Western blot analysis with a large panel of sera from patients with well characterized rheumatic diseases and with normal human sera (Fig. $1 B$ ). Most of the RA sera ( $36 / 48$ or $75 \%$ ) reacted with the $40 \mathrm{~K}$ protein. Moreover, this reactivity was correlated with their immunofluorescence intensity on the stratum corneum of the rat esophagus epithelium. However, 6 out of the 56 sera (11\%) from patients with other rheumatic diseases ( 1 of 10 with miscellaneous connective tissue diseases, 2 of 10 with psoriatic arthritis, 1 of 8 with ankylosing spondylitis, and 2 of 19 with noninflammatory rheumatic diseases) and only 1 out of the 39 sera from healthy subjects ( $3 \%$ ) weakly decorated this protein. Since it was recognized in a quite specific way by RA sera, the $40 \mathrm{~K}$ protein was further characterized: its apparent molecular weight was not affected by electrophoresis under nonreducing conditions; analyzed by Western blot after PAGE or after isoelectric focusing under nondenaturing conditions, it exhibited extensive charge heterogeneity. This was confirmed by two-dimensional electrophoretic analysis: the 40K RA antigen presented a number of isoforms with pIs ranging from 5.8 to 7.4 (Fig. $1 C$ ). Moreover, there was a slight increase in apparent molecular weight of the more acidic isoforms.

Filaggrin and the $40 \mathrm{~K}$ protein. Similar two-dimensional electrophoresis pattern and apparent molecular weight have been previously described for filaggrin (26), a basic histidinerich marker of epidermal differentiation (21). Therefore, we investigated the relationships between the RA antigen and filaggrin. We first explored whether $\mathrm{AKH} 1$, a mAb specific for human filaggrin (27), could react with the RA antigen after two-dimensional gel electrophoresis. The characteristic neutral and "comma-shaped" protein revealed by the anti-40K RA sera was also detected by AKH1 (Fig. $2 A$ ). In addition, analyzed by Western blot after PAGE under nondenaturing conditions, the epidermis extract showed identical patterns whether the blots were probed with RA sera or with AKH1 (data not shown ). We then analyzed whether AKH 1 could immunoprecipitate the $40 \mathrm{~K}$ antigen. A detergent extract was prepared from epidermis and immunoprecipitated, under conditions of high ionic strength preventing protein-protein association, with $\mathrm{AKH} 1$ and with a control $\mathrm{mAb}$; the presence of the $40 \mathrm{~K}$ protein in the immunoprecipitates was then analyzed by Western blot with 4 different anti-40K RA sera and 2 normal human sera (Fig. $2 B$ ). As expected, an immunoreactive band with an apparent molecular weight of 40,000 was detected with AKH1 in the immunoprecipitates obtained with the antifilaggrin antibody but not in those obtained with the control mAb. In the former immunoprecipitates, a band of identical mobility was also specifically visualized with the RA sera, suggesting that $\mathrm{AKH} 1$ actually immunoprecipitated the $40 \mathrm{~K}$ antigen. To confirm that the proteins recognized by $\mathrm{AKH} 1$ and the RA sera were the same, the supernatants resulting from immunoprecipitation with the antifilaggrin $\mathrm{mAb}$ were subsequently analyzed by Western blot. Results (Fig. $2 C$ ) showed that AKH1
A

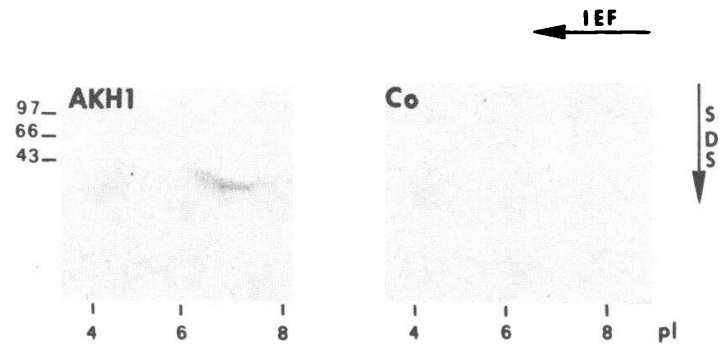

B
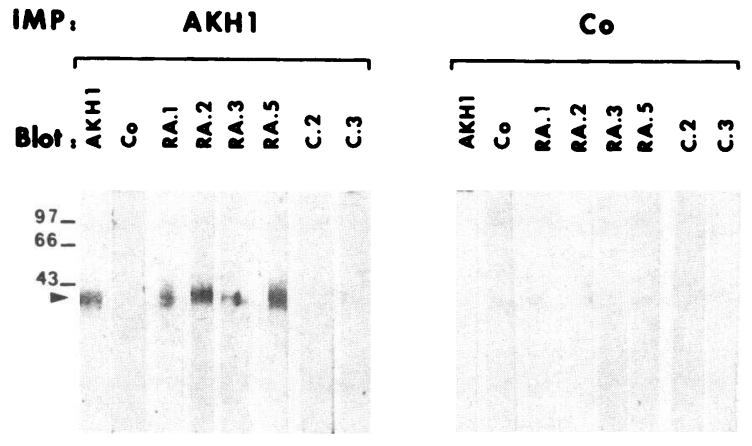

$\begin{array}{llllllll}1 & 2 & 3 & 4 & 5 & 6 & 7 & 8\end{array}$

910111213141516
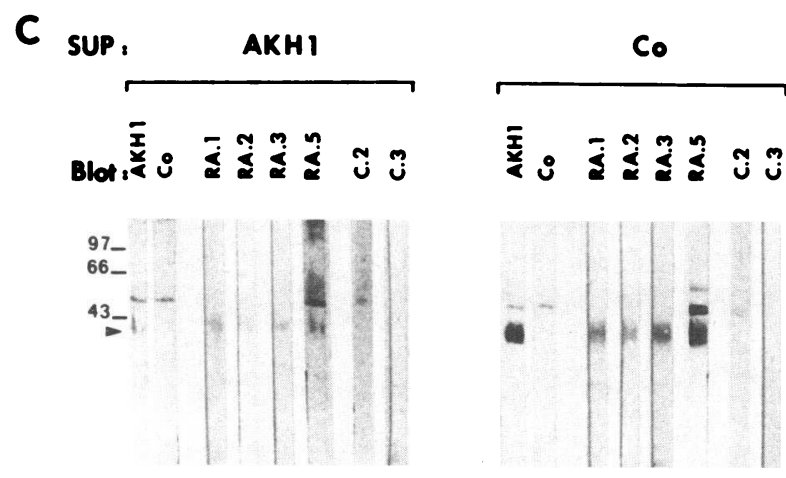

$\begin{array}{llllllll}12 & 3 & 4 & 5 & 6 & 7 & 8\end{array}$

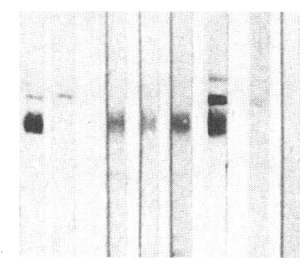

$910 \quad 11121314 \quad 1516$

Figure 2. A mAb to human filaggrin and the anti-40K RA sera recognized the same protein of human epidermis. $(A)$ Western blot of two-dimensional gels of the partially purified $40 \mathrm{~K}$ protein $(10 \mu \mathrm{g})$ probed with $\mathrm{AKH} 1$ and with an unrelated control $\mathrm{mAb}(\mathrm{Co})$. AKH 1 immunostained the $40 \mathrm{~K}$ protein. $(B)$ The detergent extract of human epidermis ( $15 \mu \mathrm{l} ; 8.2 \mathrm{mg} / \mathrm{ml}$ ) was immunoprecipitated with AKH 1 or with the control mAb and the immunoprecipitates (IMP) were analyzed by Western blot with antibodies and sera as indicated at the top of each lane with the same code as in Fig. 1. The filaggrin-crossreacting $40 \mathrm{~K}$ protein $(\bullet)$, immunoprecipitated and immunostained by AKH1 (lane 1), was also immunostained by the anti-40K RA sera (lanes 3-6). (C) The supernatants (SUP) remaining after the immunoprecipitation of the detergent extract of human epidermis with $\mathrm{AKH} 1$ or with the control mAb were also analyzed by Western blot. Both AKH1 and the anti-40K RA sera strongly stained the $40 \mathrm{~K}$ protein in supernatants recovered after immunoprecipitation with the control mAb (lanes $9,11-14$ ), but only weakly in supernatants recovered after immunoprecipitation with the anti-human filaggrin $\mathrm{mAb}$ (lanes $1,3-6$ ). The $50 \mathrm{~K}$ band occasionally stained was probably due to the murine $\mathrm{IgG}_{1}$ detected by the secondary antibody to mouse IgG (lanes $1,2,9,10$ ) or by cross-reacting rheumatoid factors (lanes $6,14)$. 
largely removed the protein recognized by the anti-40K RA sera, demonstrating complete cross-reactivity between the sera and the antifilaggrin $m A b$. The specificity of this experiment was established by the failure of an unrelated control $\mathrm{mAb}$ to deplete the 40K protein.

Analyzed by one-dimensional Western blot, the $40 \mathrm{~K}$ antigen was recognized by $\mathrm{AKH} 1$ and also by six different mAbs to human epidermal filaggrin recently produced in our laboratory, showing that filaggrin and the RA antigen present several common epitopes (Fig. $3 \mathrm{~A}$ ). The close relationship between filaggrin and the $40 \mathrm{~K}$ antigen was also confirmed by Cleveland peptide-mapping studies with $S$. aureus $\mathrm{V} 8$ protease digestion (Fig. $3 B$ ).

Despite their net difference in $\mathrm{pI}$ values, filaggrin and the purified 40K RA antigen had similar amino acid compositions, both the proteins being rich in serine, glycine, histidine, and other basic amino acids, and lacking methionine but containing citrulline (Table I). This result confirms that the $40 \mathrm{~K}$ protein was a modified form of filaggrin. Unfortunately, automated Edman degradation of the RA antigen failed to release any amino acid, as previously noticed for rat filaggrin (28).

Immunodetection of filaggrin by RA sera. We next investigated whether anti-40K RA sera really recognized mature human filaggrin. This protein, purified from human skin, was therefore analyzed by Western blot after SDS-PAGE. The purified filaggrin migrated with an approximate molecular weight of 37,000 as previously described (29), and was specifically immunostained with AKH1. All the anti-40K RA sera tested $(10 / 10)$ also detected this protein, whereas control human sera did not (Fig. $4 \mathrm{~A}$ ). Autoantibodies from RA sera were then affinity-purified on nitrocellulose-bound $40 \mathrm{~K}$ protein and used to probe immunoblots of purified filaggrin. The affinity-purified anti-40K antibodies specifically bound onto filaggrin (Fig. $4 \mathrm{~B}$ ). In addition, the reactivities towards the $40 \mathrm{~K}$ antigen of both the RA sera and the affinity-purified immunoglobulins
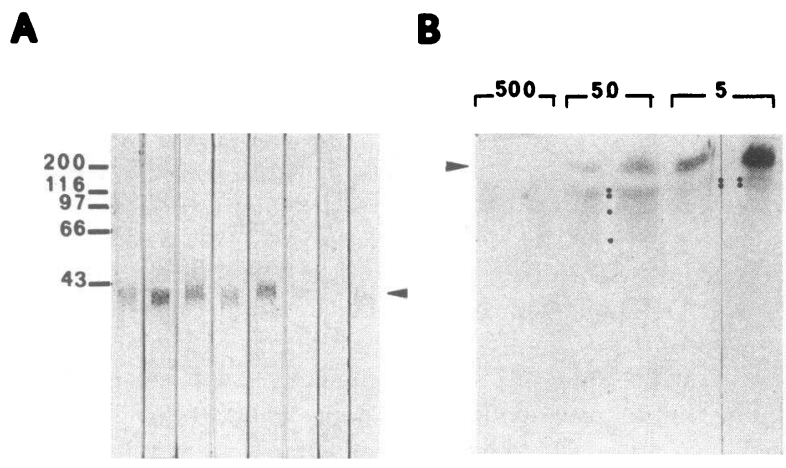

12345678

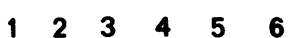

Figure 3. Relationship between the $40 \mathrm{~K}$ protein and mature basic epidermal filaggrin. $(A)$ The partially purified $40 \mathrm{~K}$ protein $(1.5 \mu \mathrm{g} /$ lane) was analyzed by Western blot with mAbs directed against six different epitopes of mature basic filaggrin (1-6), with a control $\mathrm{mAb}$ (7) or with AKHI (8). All the antifilaggrin mAbs detected a protein with the same electrophoretic mobility as the $40 \mathrm{~K}$ antigen (4). (B) The $40 \mathrm{~K}$ protein (even numbers) and mature basic filaggrin (uneven numbers) were purified from human skin. Three $\mu \mathrm{g}$ of both proteins were digested with $S$. aureus V8 protease ( 5 to $500 \mathrm{ng}$ ) in the acrylamide gel and analyzed by Western blot with $\mathrm{AKH} 1$. Immunoreactive peptides with similar mobility were found in both digests $(\bullet)$. Essentially identical results were obtained with a RA serum. $\bullet$, undigested proteins.
Table I. Amino Acid Compositions of the Purified 40K Protein and Human Epidermal Filaggrin (Residues per 100 Residues)

\begin{tabular}{|c|c|c|c|}
\hline \multirow[b]{2}{*}{ Amino acid } & \multirow{2}{*}{$\frac{\text { Deduced from cDNA clone }}{\begin{array}{c}\text { Filaggrin } \\
\text { (reference 43) }\end{array}}$} & \multicolumn{2}{|c|}{ Determined by acid hydrolysis } \\
\hline & & $\begin{array}{c}\text { Filaggrin } \\
\text { (reference 43) }\end{array}$ & $\begin{array}{l}\text { 40K protein } \\
\text { (our work) }\end{array}$ \\
\hline Asp + Asn & 8.26 & 7.65 & 7.10 \\
\hline Thr & 4.42 & 4.15 & 3.96 \\
\hline Ser & 24.92 & 22.55 & 23.47 \\
\hline Glu + Gln & 15.14 & 14.40 & 15.51 \\
\hline Pro & 0.63 & 1.00 & 1.80 \\
\hline Citrulline & & 1.25 & 1.80 \\
\hline Gly & 15.14 & 16.55 & 14.06 \\
\hline Ala & 6.63 & 5.85 & 7.10 \\
\hline Val & 1.26 & 1.35 & 2.34 \\
\hline Cys & 0.00 & Trace & Trace \\
\hline Met & 0.00 & Trace & Trace \\
\hline Ile & 0.63 & 0.75 & 0.95 \\
\hline Leu & 0.63 & 1.25 & 0.54 \\
\hline Phe & 0.32 & 0.70 & 0.30 \\
\hline Tyr & 0.63 & 1.05 & 0.60 \\
\hline Lys & 0.00 & Trace & 0.58 \\
\hline His & 11.99 & 11.95 & 10.86 \\
\hline Trp & 0.63 & 0.55 & Trace \\
\hline Arg & 9.78 & 8.35 & 9.03 \\
\hline
\end{tabular}

were not only specifically, but also completely abolished after immunoadsorption with filaggrin, confirming that the same autoantibodies recognized the $40 \mathrm{~K}$ RA antigen and human filaggrin (Fig. 5). In a control test, filaggrin did not inhibit the binding to ovalbumin of a rabbit anti-ovalbumin serum (not shown ).
A

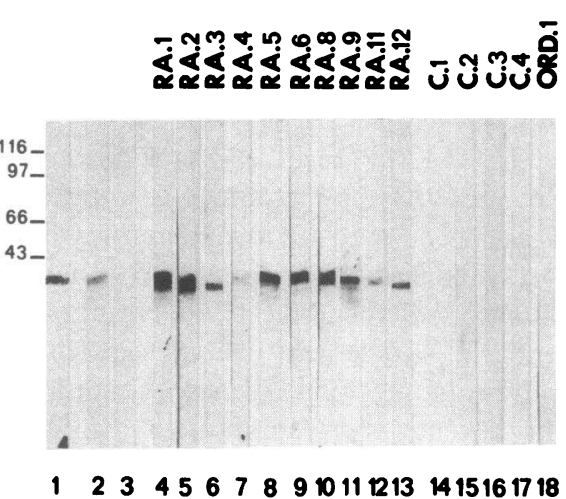

B

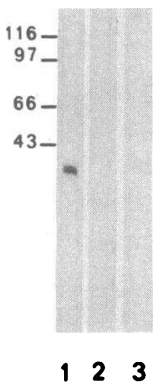

Figure 4. The anti-40K RA sera immunostained mature filaggrin purified from human epidermis. $(A)$ Basic epidermal filaggrin was purified, subjected to SDS-PAGE (0.5 $\mu$ g per lane), electrotransferred to nitrocellulose and stained with Ponceau $S$ (lane 1) or analyzed by Western blot with AKH1 (lane 2), with a control mAb (lane 3), with anti-40K RA sera (lanes 4-13) and with control sera (lanes 14-18). The sera used are coded at the top of each lane as in Fig. 1. The anti-40K RA sera specifically immunodetected the purified filaggrin. $(B)$ Western blot on filaggrin was also performed with antibodies affinity-purified from a RA serum on nitrocellulose-bound $40 \mathrm{~K}$ antigen (lane 1) or on control protein (lane 2). Antibodies were also affinity-purified from a control serum on the $40 \mathrm{~K}$ antigen (lane 3 ). The affinity-purified anti-40K RA antibodies specifically reacted with filaggrin. 


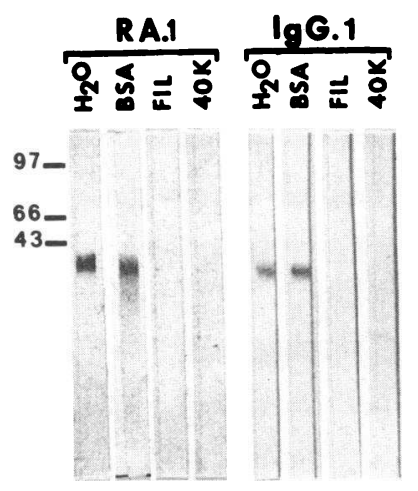

Figure 5. Immunoadsorption of RA sera with purified human filaggrin inhibited their reactivity towards the $40 \mathrm{~K}$ protein. The partially purified $40 \mathrm{~K}$ protein $(1.5 \mu \mathrm{g}$ per lane) was analyzed by Western blot with an anti-40K RA serum (RA.1) and with affinity-purified anti-40K protein antibodies obtained from the same serum (IgG.1). Before immunoblotting, both the serum or the affinity-purified antibodies were preincubated, as indicated at the top of each lane, with purified $40 \mathrm{~K}$ protein $(40 \mathrm{~K})$, purified basic filaggrin (FIL), BSA, or with an equal volume of water $\left(\mathrm{H}_{2} \mathrm{O}\right)$. Preincubation with filaggrin or with the $40 \mathrm{~K}$ protein completely inhibited the immunoreaction of the serum and of the affinity-purified antibodies towards the $40 \mathrm{~K}$ protein, whereas preincubation with BSA did not. Identical results were obtained with several RA sera.

To demonstrate that the antifilaggrin/anti-40K protein autoantibodies were responsible for the specific immunofluorescence pattern observed with RA sera on rat esophagus epithelium, 2 anti-40K RA sera were analyzed by indirect immunofluorescence on this tissue before and after immunoadsorption on both filaggrin and the $40 \mathrm{~K}$ protein. A significant inhibition of the fluorescence intensity on the stratum corneum was observed when the sera were preincubated with purified filaggrin or with the $40 \mathrm{~K}$ antigen but no detectable change was observed after immunoadsorption with an equal amount of BSA (Fig. 6 ). These results indicate that both the $40 \mathrm{~K}$ protein and filaggrin share some epitopes with the rat esophagus stratum corneum. In contrast to the complete adsorption of immunoblotting reactivity against the $40 \mathrm{~K}$ protein or filaggrin, immunoflu-
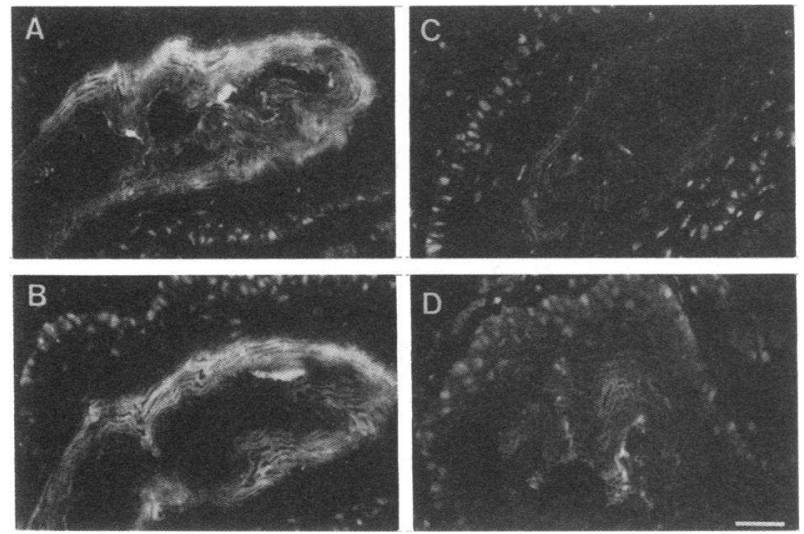

Figure 6. Immunoadsorption of RA sera with the purified $40 \mathrm{~K}$ protein or with purified human filaggrin inhibited their specific labeling of rat esophagus. An anti-40K RA serum was analyzed, using indirect immunofluorescence, without any immunoadsorption $(A)$ and after immunoadsorption with BSA $(B)$, with purified basic filaggrin $(C)$, or with the purified $40 \mathrm{~K}$ protein $(D)$. With or without incubation with albumin, the serum showed a typical, laminated and intense, labeling of the stratum corneum of the rat esophagus epithelium. Immunoadsorption with both purified human proteins produced a major decrease of the labeling. Note that the labeling of basal cell nuclei by antinuclear antibodies present in the serum was not modified after immunoadsorption. Scale bar, $80 \mu \mathrm{m}$. orescence reactivity against the stratum corneum was never completely abolished, even with a large excess of purified filaggrin, suggesting the existence of antibodies directed to other antigens of the stratum corneum of the rat esophagus. More probably however, this result indicates that discontinuous or conformational epitopes present on filaggrin may be lost during the purification steps.

\section{Discussion}

Using indirect immunofluorescence, antibodies of the IgG class directed against components of rat esophagus and human skin have been described as highly specific for RA (6-15). Until now, the presence of these autoantibodies, the so-called "antikeratin antibodies," in the serum of patients is the most specific serological criterion for the disease. Our study provides the first detailed biochemical characterization of the human epidermal antigen recognized by the RA sera. We demonstrated that $75 \%$ of RA sera reacted in Western blot with a $40 \mathrm{~K}$ protein of human epidermis that was weakly detected by only $7 \%$ of non-RA sera. Since the immunofluorescence intensity produced by the RA sera on rat esophagus correlated with their reactivity against the $40 \mathrm{~K}$ protein in Western blot and was largely decreased by immunoadsorption with the $40 \mathrm{~K}$ protein, the RA-specific labeling of esophagus epithelium was most probably due to these anti-40K antibodies. The $40 \mathrm{~K}$ antigen was identified as a neutral/acidic modified form of human filaggrin and is probably identical to an AKH1-recognized protein recently described in epidermal extracts but not further characterized (30). The immunoaffinity-purified anti-40K antibodies were also shown to react with basic mature filaggrin, confirming this cytokeratin filament-aggregating protein as a major target of autoantibodies specific for RA. The immunoblotting detection of this autoantibody against filaggrin may be useful to the serological diagnosis of RA, in particular to differentiate RA from other arthritic diseases in the early stages of these disorders.

Filaggrin is a basic intermediate filament-associated protein that is involved in the aggregation of cytokeratin filaments during terminal differentiation in mammalian epidermis. It is synthesized as a large heavily phosphorylated, and therefore acidic, precursor (profilaggrin). During the late steps of normal differentiation, this precursor is dephosphorylated and cleaved to release functional filaggrin molecules (18-21). What is the origin of the $40 \mathrm{~K}$ filaggrin isoform we have identified? It could be an undiscovered intermediate in the processing pathway from the acidic profilaggrin to the basic filaggrin, or a degradation product of profilaggrin that is known to be proteolytically labile; such a degradation polypeptide, with a pI of 6.9 and a slightly higher apparent molecular weight than mature filaggrin, has been described in the rat (31). However, a protein with a pI between those of profilaggrin and filaggrin has never been reported after ${ }^{32} \mathrm{P}$-phosphate labeling of human skin. Moreover, RA sera did not immunodetect profilaggrin on Western blot and did not decorate the keratohyalin granules (our unpublished observations) where profilaggrin is stored in human epidermis. Alternatively, the $\mathrm{pI}$ of this slightly slower migrating isoform may result from the extensive conversion of the amino acid arginine to citrulline, a reaction previously proposed by Harding and Scott to explain the characteristic "comma-shaped" electrophoretic migration of filaggrin (26). 
Further characterization of the $40 \mathrm{~K}$ antigen will be necessary to conclusively answer this question.

Another autoantibody, the antiperinuclear factor, directed against perinuclear granules of the epithelial cells of the human buccal mucosa, has also been described in RA (9, 32-35). Since it was found, by double immunofluorescence, that (pro)filaggrin colocalized with the perinuclear granules and since a correlation was found between the titer of antiperinuclear factors and the titer of the so-called "antikeratin antibodies" (35), it is tempting to speculate that these two autoantibodies are identical or at least closely related. However, most of the tested sera containing the antiperinuclear factor were found not to react or only to react weakly on Western blot with AKH1-reactive molecules from buccal cells (35). This apparent discrepancy with our results may simply reflect differences in sensitivity of the assays.

Although their importance in diagnosis has been established, the role as well as the origin of antifilaggrin autoantibodies in the serum of RA patients remain unclear. These autoantibodies may be derived from the destruction of synovial cells containing filaggrin, or more probably containing cross-reactive molecules, since the synovial lining cells are not considered to express filaggrin. In this context, it is interesting to note that filaggrin, like many other autoantigens $(36,37)$, displays unusual charge properties since it is highly basic, and is associated into macromolecular complexes with other autoantibody-reactive proteins, i.e., cytokeratins recognized by naturally occurring autoantibodies (38).

The importance of $T$ cells in the pathogenesis of RA is becoming increasingly clearer. However, the antigenic specificity of the involved $\mathrm{T}$ cells is not known, even though a reactivity to heat shock proteins has been implicated (39-41). Therefore it will be important to determine whether filaggrin or filaggrin-related molecules are involved in this process.

The identification of the epitope(s) with which the antifilaggrin autoantibodies react will probably suggest possible mechanisms of their production, may provide more insight into the pathogenesis of RA, in particular in the event of molecular mimicry, and may even suggest new approaches to therapy, in a way similar to that successfully used in experimental allergic encephalomyelitis (42).

\section{Acknowledgments}

We thank Professor A. Fournié and Professor B. Fournié (Clinique de Rhumatologie, CHU Purpan, Toulouse, France) for providing the patient sera, Professor M. Costagliola (Service de Chirurgie Plastique, CHU Rangueil, Toulouse) for giving us human skin, Dr. G. Sommé (Clonatec, Paris, France) for his useful advice, and M.-F. Isaïa for her excellent technical assistance.

This study was supported by Clonatec S. A., the "Région MidiPyrénées," and the "Association pour la Recherche sur la Polyarthrite."

\section{References}

1. Harris, E. D. 1990. Rheumatoid arthritis: pathophysiology and implications for therapy. N. Engl. J. Med. 322:1277-1289.

2. Shmerling, R. H., and T. L. Delbanco. 1991. The rheumatoid factor: an analysis of clinical utility. Am. J. Med. 91:528-534.

3. Steiner, G., K. Hartmuth, K. Skriner, I. Maurer-Fogy, A. Sinski, E. Thalmann, W. Hassfeld, A. Barta, and J. S. Smolen. 1992. Purification and partial sequencing of the nuclear autoantigen RA33 shows that it is indistinguishable from the A2 protein of the heterogeneous nuclear ribonucleoprotein complex. $J$. Clin. Invest. 90:1061-1066.
4. Baboonian, C., P. J. W. Venables, D. G. Williams, R. O. Williams, and R. N. Maini. 1991. Cross reaction of antibodies to a glycine/alanine repeat sequence of Epstein-Barr virus nuclear antigen-1 with collagen, cytokeratin, and actin. Ann. Rheum. Dis. 50:772-775.

5. Kouri, T., J. Petersen, G. Rhodes, K. Aho, T. Palosuo, M. Heliövaara, H. Isomäki, R. von Essen, and J. H. Vaughan. 1990. Antibodies to synthetic peptides from Epstein-Barr nuclear antigen-1 in sera of patients with early rheumatoid arthritis and in preillness sera. J. Rheumatol. 17:1442-1449.

6. Young, B. J. J., R. K. Mallya, R. D. G. Leslie, C. J. M. Clark, and T. J. Hamblin. 1979. Antikeratin-antibodies in rheumatoid arthritis. Br. Med. J. 2:9799.

7. Quismorio, F. P., Jr., R. L. Kaufman, T. Beardmore, and E. S. Mongan. 1983. Reactivity of serum antibodies to the keratin layer of rat esophagus in patients with rheumatoid arthritis. Arthritis Rheum. 26:494-499.

8. Serre, G., C. Vincent, F. Lapeyre, B. Fournié, J.-P. Soleilhavoup, and A. Fournié. 1986. Anticorps anti-stratum corneum d'oesophage de rat, auto-anticorps anti-kératines épidermiques et anti-épiderme dans la polyarthrite rhumatoïde et différentes affections rhumatologiques. Rev. Rhum. Mal. Ostéo-Artic. 53:607-614

9. Johnson, G. D., A. Carvalho, E. J. Holborow, D. H. Goddard, and G. Russel. 1981. Antiperinuclear factor and keratin antibodies in rheumatoid arthritis. Ann. Rheum. Dis. 40:263-266.

10. Miossec, P., P. Youinou, P. Le Goff, and M. P. Moineau. 1982. Clinical relevance of antikeratin antibodies in rheumatoid arthritis. Clin. Rheumatol. 1:185-189.

11. Ordeig, J., and J. J. Guardia. 1984. Diagnostic value of antikeratin antibodies in rheumatoid arthritis. J. Rheumatol. 11:602-604.

12. Hajiroussou, V. J., J. Skingle, A. P. Gillett, and M. J. Webley, 1985 Significance of antikeratin antibodies in rheumatoid arthritis. J. Rheumatol. 12:57-59.

13. Kirstein, H., and F. K. Mathiesen. 1987. Antikeratin antibodies in rheumatoid arthritis. Methods and clinical significance. Scand. J. Rheumatol. 16:331-337.

14. Vincent, C., G. Serre, F. Lapeyre, B. Fournié, C. Ayrolles, A. Fournié, and J.-P. Soleilhavoup. 1989. High diagnostic value in rheumatoid arthritis of antibodies to the stratum corneum of rat oesophagus epithelium, so-called "antikeratin antibodies." Ann. Rheum. Dis. 48:712-722.

15. Vincent, C., G. Serre, B. Fournié, A. Fournié, and J.-P. Soleilhavoup. 1991. Natural IgG to epidermal cytokeratins vs IgG to the stratum corneum of the rat oesophagus epithelium, so-called "antikeratin antibodies", in rheumatoid arthritis and other rheumatic diseases. J. Autoimmun. 4:493-505.

16. Paimela, L., M. Gripenberg, P. Kurki, and M. Leirisalo-Repo. 1992. Antikeratin antibodies: diagnosis and prognostic markers for early rheumatoid arthritis. Ann. Rheum. Dis. 51:743-746.

17. Kurki, P., K. Aho, T. Palosuo, and M. Heliövaara. 1992. Immunopathology of rheumatoid arthritis: antikeratin antibodies precede the clinical disease. Arthritis Rheum. 35:914-917.

18. Dale, B. A., K. A. Holbrook, and P. M. Steinert. 1978. Assembly of stratum corneum basic protein and keratin filaments in macrofibrils. Nature (Lond.). 276:729-731.

19. Steinert, P. M., J. S. Cantieri, D. C. Teller, J. D. Lonsdale-Eccles, and B. A. Dale. 1981. Characterization of a class of cationic proteins that specifically interact with intermediate filaments. Proc. Natl. Acad. Sci. USA 78:4097-4101.

20. Gan, S.-Q., O. W. McBride, W. W. Idler, N. Markova, and P. M. Steinert. 1990. Organization, structure and polymorphisms of the human profilaggrin gene. Biochemistry. 29:9432-9440.

21. Dale, B. A., K. A. Resing, and P. V. Haydock. 1990. Filaggrins. In Cellular and Molecular Biology of Intermediate Filaments. R. D. Goldman, and P. M. Steinert, editors. Plenum Press, New York/London. 349-412.

22. Arnett, F. C., S. M. Edworthy, D. A. Bloch, D. J. McShane, J. F. Fries, N. S. Cooper, L. A. Healey, S. R. Kaplan, M. H. Liang, H. S. Luthra et al. 1988. The American Rheumatism Association 1987 revised criteria for the classification of rheumatoid arthritis. Arthritis Rheum. 31:315-324.

23. Mils, V., M. Simon, C. Vincent, S. Michel, and G. Serre. 1992. A new late differentiation antigen of human cornified epithelia, defined by the monoclonal antibody D40-10, characterizes a subpopulation of keratohyalin granules. Eur. J. Dermatol. 5:100-108.

24. Simon, M., P.-F. Spahr, and F. Dainous. 1989. The proteins associated with the soluble form of $\mathrm{p} 36$, the main target of the src oncogene in chicken fibroblasts, are glycolytic enzymes. Biochem. Cell Biol. 67:740-748.

25. Cleveland, D. W., S. G. Fischer, M. W. Kirschner, and U. K. Laemmli. 1977. Peptide mapping by limited proteolysis in sodium dodecyl sulfate and analysis by gel electrophoresis. J. Biol. Chem. 252:1102-1106.

26. Harding, C. R., and I. R. Scott. 1983. Histidine-rich proteins (filaggrins) structural and functional heterogeneity during epidermal differentiation. J. Mol. Biol. 170:651-673.

27. Dale, B. A., A. M. Gown, P. Fleckman, J. R. Kimball, and K. A. Resing. 1987. Characterization of two monoclonal antibodies to human epidermal keratohyalin: reactivity with filaggrin and related proteins. J. Invest. Dermatol. 88:306-313. 
28. Lonsdales-Eccles, J. D., D. C. Teller, and B. A. Dale. 1982. Characterization of a phosphorylated form of the intermediate filament-aggregating protein filaggrin. Biochemistry. 21:5940-5948.

29. Lynley, A. M., and B. A. Dale. 1983. The characterization of human epidermal filaggrin. Biochim. Biophys. Acta. 744:28-35.

30. Réano, A., Y. Sarret, and J. Thivolet. 1990. GP37 is different from filaggrin. J. Invest. Dermatol. 95:70-73.

31. Lonsdales-Eccles, J. D., J. A. Haugen, and B. A. Dale. 1980. A phosphorylated keratohyalin-derived precursor of epidermal stratum corneum basic protein. J. Biol. Chem. 255:2235-2238.

32. Nienhuis, R. L. F., and E. Mandema. 1964. A new serum factor in patients with rheumatoid arthritis: the antiperinuclear factor. Ann. Rheum. Dis. 23:302305.

33. Sondag-Tschroots, I. R. J. M., C. Aaij, J. W. Smit, and T. E. W. Feltkamp 1979. The antiperinuclear factor. 1. The diagnostic significance of the antiperinuclear factor for rheumatoid arthritis. Ann. Rheum. Dis. 38:248-251.

34. Veys, E. M., F. De Keyser, K. De Vlam, and G. Verbruggen. 1990. The antiperinuclear factor. Clin. Exp. Rheumatol. 8:429-431.

35. Hoet, R. M., A. M. Th. Boerbooms, M. Arends, D. J. Ruiter, and W. J. Van Venrooij. 1991. Antiperinuclear factor, a marker autoantibody for rheumatoid arthritis: colocalisation of the perinuclear factor and profilaggrin. Ann. Rheum. Dis. 50:611-618.

36. Brendel, V., J. Dohlman, B. E. Blaisdell, and S. Karlin. 1991. Very long charge runs in systemic lupus erythematosus-associated autoantigens. Proc. Natl. Acad. Sci. USA 88:1536-1540.
37. Tan, E. M. 1989. Antinuclear antibodies: diagnostic markers for autoimmune diseases and probes for cell biology. Adv. Immunol. 44:93-151.

38. Serre, G., C. Vincent, R. Viraben, and J.-P. Soleilhavoup. 1987. Natural IgG and IgM autoantibodies to epidermal keratins in normal human sera. I. ELISA titration; immunofluorescence study. J. Invest. Dermatol. 88:21-27.

39. Young, R. A. 1990. Stress proteins and immunology. Annu. Rev. Immunol. 8:401-4420.

40. van Eden, W., J. E. R. Thole, R. van der Zee, A. Noordzij, J. D. A. van Embden, E. J. Hensen, and I. R. Cohen. 1988. Cloning of the mycobacterial epitope recognized by $\mathrm{T}$ lymphocytes in adjuvant arthritis. Nature (Lond.). 331:171-173.

41. Hermann, E., A. W. Lohse, R. Van der Zee, W. Van Eden, W. J. Mayet, P. Probst, T. Porolla, K.-H. Meyer zum Büschenfelde, and B. Fleischer. 1991. Stimulation of synovial fluid mononuclear cells with the human 65-kD heat shock protein or with live enterobacteria leads to preferential expansion of TCR- $\gamma \delta^{+}$ lymphocytes. Eur. J. Immunol. 21:2139-2143.

42. Wraith, D. C., H. O. McDevitt, L. Steinman, and H. Acha-Orbea. 1989. T cell recognition as the target for immune intervention in autoimmune disease. Cell. 57:709-715.

43. McKinley-Grant, L. J., W. W. Idler, I. A. Bernstein, D. A. D. Parry, L. Cannizzaro, C. M. Croce, K. Huebner, S. R. Lessin, and P. M. Steinert. 1989. Characterization of a cDNA clone encoding human filaggrin and localization of the gene to chromosome region 1q21. Proc. Natl. Acad. Sci. USA 86:4848-4852. 